\title{
Motivation and Characterization of Finnish Meat Inspection Veterinarians
}

\author{
By M. Rahkio ${ }^{l}$, A. Uutela $^{2}$ and H. Korkeala ${ }^{l}$ \\ ${ }^{1}$ Department of Food and Environmental Hygiene, Faculty of Veterinary Medicine, University of Helsinki, and \\ ${ }^{2}$ National Public Health Institute, Helsinki, Finland.
}

\begin{abstract}
Rahkio, M., A. Uutela and H. Korkeala: Motivation and characterization of Finnish meat inspection veterinarians. Acta vet. scand. 1995, 36, 563-570. - A questionnaire survey on the factors affecting the motivation and work attitudes of Finnish veterinary meat inspectors was conducted. Traditional meat inspection on the slaughtering line and in the emergency department took up most of the weekly work time $(15.8 \%$ and $15.8 \%$, respectively). Emergency slaughtering $(29 \%)$ and general hygiene control $(29 \%)$ were considered the most important tasks of veterinary meat inspectors. Assurance of meat safety $(68 \%)$ was cited as the most important single reason for meat inspection. Veterinary meat inspectors were of the opinion that they do not play an important role in the training of slaughterhouse personnel, although they considered training to be a very important means for promoting hygienic work methods among workers. Three orientations of the respondents toward meat inspection and slaughterhouse operations were revealed from the survey: hygiene, education, and emergency slaughter work orientation. Meat inspection veterinarians may feel isolated from the other personnel responsible for maintaining quality and hygiene. The orientation and possible isolated position of veterinary meat inspectors should be given more attention in both the basic undergraduate and postgraduate training of veterinary meat inspectors.
\end{abstract}

slaughterhouse; working environment; factor analysis; veterinary meat inspectors; workers; questionnaire survey.

\section{Introduction}

The study of hygiene involves both the microbiological and human behavioural sciences. Good hygiene is attained through co-operation and by the acceptance of hygienic working methods, whereas poor hygiene is the result of mistakes and hygienic faults. In spite of advances in the development of new machinery and equipment in the food and meat industry, craftmanship and manual labor still play important roles in the industry (Seligmann \& Rosenbluth 1975, Gerats 1990, Konuma et al. 1994). In particular, the hands of slaughterhouse workers and other personnel in the meat industry have been found to be more contaminated than those of workers in other branches of the food industry (Witt \& Kampelmacher 1981). The microbiological contamination of the hands of slaughterhouse personnel may compromise their hygiene. Thus, the adoption of proper slaughter techniques and hygienic work methods is especially important in slaughterhouses. The role of motivation in the adoption of hygienic work methods in relation to the meat industry has been discussed for a number of years (Gerats et al. 1982, Gerats 1987, Tazelaar 1987). The studies of Tazelaar (1987) and Gerats (1987) have shown that hygienic working methods are no longer "simply a matter of motivation, in which very little can be changed" 
according to Tazelaar (1987). Three basic elements are needed in order to achieve hygienic working procedures (Gerats 1987, Tazelaar 1987). First, training and knowledge on the background and consequences of poor or good hygienic behaviour must be provided. The second element is the ability to act hygienically, and the third involves social support for hygienic work practices. Giving encouragement by means of positive feedback for work correctly performed is also an important contributing factor.

Finnish meat inspection legislation (Anon. 1960 , Anon. 1989) requires that veterinary meat inspectors shall be responsible for maintaining the general hygiene of the slaughterhouse where they are regularly employed. The same principle is included in current legislation (Anon. 1994a, 1994b). On the basis of Tazelaar's (1987) theory, veterinary meat inspectors could therefore be key persons in promoting the acceptance of hygienic work methods. Veterinary meat inspectors can be both trainers of hygienic work methods and givers of positive feedback for work performed correctly. The purpose of this study was to investigate the motivation and attitudes of Finnish meat inspection veterinarians employed in slaughterhouses.

\section{Materials and methods}

\section{Data collection}

In May 1990 a questionnaire on the motivational level of hygiene supervisory personnel was mailed to all of the 50 Finnish veterinary meat inspectors working in the 36 red meat slaughterhouses of Finland. Of the inspectors, $41(84 \%)$ responded, representing $30(83 \%)$ slaughterhouses. Of these respondents, 37 $(90 \%)$ were employed full-time and $4(10 \%)$ part-time as meat inspectors. The work hours of these part-time meat inspectors varied from 14 to $19 \mathrm{~h}$ per week.

\section{Statistical analysis}

Results were analyzed by the Statistical Package for the Social Sciences, CSPSS, SPSS Inc. Chicago, Illinois, USA. Variables considered continuous and normally distributed were given as means, and categorical ones as medians (Danzart 1986). Factor analysis was used to combine the results concerning the attitude of the respondents. The factors from the factor analysis were varimax rotated to clear the interpretation of analysis. The eigenvalue of one was used as a limit of acceptance of the factor to the varimax rotation. After varimax rotation the factor scores were computed with the help of the factor loadings. The factors were used as new variables and factor scores as values of these new factor variables in the further analyses (Ranta et al. 1991). The t-test, median test, and the analysis of variance were used to study the effect of these new factor variables on the use of time and other evaluations of the respondents.

\section{Results and Discussion}

Work tasks of veterinary meat inspectors

Working time spent on different tasks and evaluations of the possibilities to run the tasks are given in Table 1. The greatest amount of time was spent working on the line or in the emergency department. Work related to worker training represented a minor part of the work week. Veterinary meat inspectors were of the opinion that their most important tasks were emergency slaughtering and general hygiene control. The training of workers was most often $(20 \%)$ classified as the least important duty of the meat inspection veterinarian. Meat safety was named as the single most important reason for meat inspection (Table 2). According to the respondents, the commercial and economic principles influenced a lot compared to hygienic principles, when the management of the 
Table 1. Time spent on different tasks in percentages of weekly working hours and evaluation of the importance of the tasks, legislative support and sufficiency of knowledge and time for these tasks by Finnish veterinary meat inspectors.

\begin{tabular}{|c|c|c|c|c|c|c|}
\hline \multirow[t]{2}{*}{ Task } & \multirow[t]{2}{*}{ Time (\%) } & \multicolumn{2}{|c|}{$\begin{array}{l}\text { Importance } \\
\text { of tasks }\end{array}$} & \multirow[t]{2}{*}{$\begin{array}{l}\text { Legislative } \\
\text { support }\end{array}$} & \multirow[t]{2}{*}{$\begin{array}{l}\text { Sufficiency } \\
\text { of knowledge }\end{array}$} & \multirow[t]{2}{*}{$\begin{array}{l}\text { Sufficiency } \\
\text { of time }\end{array}$} \\
\hline & & $\mathrm{n}^{\mathrm{a}}$ & $\%^{\mathrm{a}}$ & & & \\
\hline Animal protection & $3.2 \pm 2.9^{\mathrm{b}}$ & 4 & 7 & $3(1-4)^{c}$ & $2(1-4)^{\mathrm{c}}$ & $2(1-4)^{c}$ \\
\hline Inspection of live animals & $8.6 \pm 5.3$ & 8 & 15 & $3(1-5)$ & $2(1-4)$ & $2(1-4)$ \\
\hline Administration & $5.4 \pm 6.8$ & 0 & 0 & $3(2-5)$ & $3(1-5)$ & $3(1-5)$ \\
\hline Training of workers & $3.0 \pm 2.6$ & 0 & 0 & $3(2-5)$ & $3(1-5)$ & $3(1-5)$ \\
\hline \multicolumn{7}{|l|}{ Following literature and } \\
\hline new legislation & $4.8 \pm 3.6$ & 2 & 4 & $3(2-4)$ & $2(1-4)$ & $3(1-5)$ \\
\hline Laboratory work & $9.8 \pm 8.0$ & 0 & 0 & $3(1-5)$ & $2(1-5)$ & $2(1-4)$ \\
\hline Work on slaughtering line & $15.8 \pm 17.8$ & 6 & 11 & $2(1-3)$ & $2(1-3)$ & $3(1-5)$ \\
\hline Emergency slaughtering & $15.8 \pm 12.1$ & 16 & 29 & $2(1-3)$ & $2(1-3)$ & $2(1-4)$ \\
\hline Work concerning weighing & $2.3 \pm 2.2$ & 0 & 0 & $2(1-4)$ & $2(1-4)$ & $3(1-5)$ \\
\hline Control of meat processing & $5.1 \pm 5.6$ & 3 & 5 & $3(1-5)$ & $3(1-5)$ & $3(2-5)$ \\
\hline Certificates & $9.5 \pm 5.2$ & 0 & 0 & $2(1-3)$ & $2(1-4)$ & $2(1-5)$ \\
\hline General hygiene control & $10.6 \pm 8.2$ & 16 & 29 & $3(2-5)$ & $2(1-4)$ & $3(2-4)$ \\
\hline
\end{tabular}

a Number and percentage of respondents who defined this task as the most important of the tasks.

b Mean \pm standard deviation of working time in percentages.

c Median and range (in parentheses) on a scale: $1=$ very good, $2=$ good, $3=$ moderate, $4=$ poor, $5=$ very poor.

slaughterhouse made hygiene related decisions.

\section{Motivation of veterinary meat inspectors and slaughterhouse personnel}

Veterinary meat inspectors were asked to rank the factors having positive effects on their work motivation, in order of importance (Table 3) and to evaluate the importance of the factors in general. Factor analysis of these responses revealed 3 factors. Table 4 shows the medians for the factors having positive impacts on the hygienic work methods of personnel according to respondents. Veterinary meat inspectors considered workers' attitude to be the variable having the greatest effect on hygienic work methods. The worker as such was considered as superior to any situational or environmental factor. The responses were analyzed by factor analysis and the 3 factors of the analysis are shown in Table 4.
Differences according to new factor variables The responses concerning the use of time and evaluation of the importance of the work (Table 1) were tested according to 6 new variables from factor analysis (Tables 3 and 4). Those re-

Table 2. Importance of the reasons for meat inspection by Finnish veterinary meat inspectors.

\begin{tabular}{lcc}
\hline Reason & \multicolumn{2}{c}{ Importance of reasons } \\
\cline { 2 - 3 } & $\mathrm{n}^{\mathrm{a}}$ & $\%^{\mathrm{a}}$ \\
\hline Animal protection & 3 & 7 \\
Commercial agreements & 0 & 0 \\
Legality & 4 & 10 \\
Processing of farm products & 1 & 2 \\
Tradition & 1 & 2 \\
Meat safety & 28 & 68 \\
Meat quality & 4 & 10 \\
\hline
\end{tabular}

a Number and percentage of respondents who defined this reason as the most important one for meat inspection. 
Table 3. Significance and conglomeration of factors having positive effects on the work motivation of veterinary meat inspectors.

\begin{tabular}{|c|c|c|c|c|c|c|}
\hline \multirow[t]{2}{*}{ Factor } & \multicolumn{3}{|c|}{ Effect on motivation } & \multicolumn{3}{|c|}{ Factor loadings of factor analysis } \\
\hline & $\mathrm{m}^{\mathrm{a}}$ & $n^{b}$ & $\%^{b}$ & $\begin{array}{l}\text { Factor } 1 \\
\text { Hygiene }^{c}\end{array}$ & $\begin{array}{l}\text { Factor } 2 \\
\text { Education }^{\mathrm{c}}\end{array}$ & $\begin{array}{l}\text { Factor } 3 \\
\text { Self-interest }^{c}\end{array}$ \\
\hline Hygiene level of workplace & $2(1-4)$ & 2 & 5 & .826 & .309 & .176 \\
\hline Positive atmosphere of workplace & $2(1-4)$ & 4 & 9 & .907 & .042 & .190 \\
\hline Meaningfulness of work & $2(1-3)$ & 16 & 37 & .794 & .203 & .110 \\
\hline Education & $2(1-3)$ & 4 & 9 & .247 & .811 & .166 \\
\hline Challenge of work & $2(1-3)$ & 2 & 5 & .512 & .622 & -.071 \\
\hline Importance of work & $2(1-3)$ & 7 & 16 & -.012 & .861 & .189 \\
\hline Training opportunities & $2(1-3)$ & 5 & 12 & .190 & .309 & .671 \\
\hline Salary & $2(1-3)$ & 3 & 7 & .292 & .251 & .636 \\
\hline Easiness of work & $3(1-5)$ & 0 & 0 & .132 & .047 & .830 \\
\hline \multirow[t]{2}{*}{ Benefits } & $3(1-5)$ & 0 & 0 & .393 & .219 & -.531 \\
\hline & & & & $3.97^{\mathrm{d}}$ & $1.63^{\mathrm{d}}$ & $1.26^{\mathrm{d}}$ \\
\hline
\end{tabular}

a Median and range (in parentheses) on the scale: $1=$ increases substantially, $2=$ increases to a certain degree, $3=$ no effect, $4=$ decreases to a certain degree, $5=$ substantially decreases work motivation.

b Number and percentage of respondents who defined this factor as the most important factor for work motivation.

c Factor 1 was called the hygienic orientation factor, factor 2 the education orientation factor and factor 3 the benefits orientation factor on the basis of the original variables that had high factor loadings. These new factors were saved as 3 new variables. The limit of zero of this new variable was used in defining the respondents into hygiene and non-hygiene, education and non-education and benefits and non-benefits oriented ones for the analyses of differences between oriented and non-oriented ones.

d Eigenvalue of the factor. Eigenvalue means how much the factor describes of the variation of original variables.

spondents who placed a high value on hygiene in their own work attached significantly less importance to keeping up to date on the literature and legislation than did those who did not value hygiene in their work. Respondents who valued education spent significantly more time in the supervision of meat processing than respondents who did not value education. Respondents who valued education also assigned the supervision of meat procesing a greater importance. Respondents whose priorities were personal gain, i.e. the self-interest factor, considered laboratory work to be significantly less important than respondents who did not stress the self-interest factor.

Those respondents who emphasized the hy- gienic level of the working place as a factor encouraging workers to adopt hygienic working methods spent significantly more time on general hygiene control than those who did not emphasize such factor. Those who emphasized pay by the piece, i.e. the line work factor, as an incentive factor, spent significantly less time on the inspection of living animals and on filling out certificates than those who did not emphasize line work factor. They also considered slaughtering line work significantly more important. Respondents who valued attitude and salary, i.e. the self-interest worker related factor, spent significantly less time on administrative tasks and on keeping up with legislation and the literature, and more time on emergency 
Table 4. Significance and conglomeration of factors having a positive influence on hygienic working methods of workers according to veterinary meat inspectors.

\begin{tabular}{|c|c|c|c|c|}
\hline \multirow[t]{2}{*}{ Factor } & \multirow{2}{*}{$\begin{array}{l}\text { Perceived impact on } \\
\text { hygienic working } \\
\text { methods }\end{array}$} & \multicolumn{3}{|c|}{ Factor loadings of factor analysis } \\
\hline & & $\begin{array}{l}\text { Factor } 1 \\
\text { Hygiene }^{\mathrm{a}}\end{array}$ & $\begin{array}{l}\text { Factor } 2 \\
\text { Line work }^{\mathrm{a}}\end{array}$ & $\begin{array}{l}\text { Factor } 3 \\
\text { Self-interest }\end{array}$ \\
\hline Sufficient workforce & $2(1-4)^{b}$ & .560 & .173 & .542 \\
\hline Working equipment & $2(1-4)$ & .815 & -.134 & .171 \\
\hline Atmosphere of workplace & $2(1-4)$ & .817 & -.096 & .186 \\
\hline Hygienic level of workplace & $2(1-3)$ & .924 & -.094 & .034 \\
\hline Pay by the piece & $4(2-5)$ & -.165 & .650 & .066 \\
\hline Large size of slaughterhouse & $3(1-5)$ & -.148 & .789 & -.103 \\
\hline Small size of slaughterhouse & $4(2-5)$ & .229 & .729 & .069 \\
\hline Attitude & $1(1-5)$ & -.000 & -.466 & .740 \\
\hline Bonus for good work & $2(1-3)$ & .248 & .095 & .818 \\
\hline \multirow[t]{2}{*}{ Training } & $2(1-4)$ & .164 & -.466 & .279 \\
\hline & & $3.35^{\mathrm{c}}$ & $1.97^{\mathrm{c}}$ & $1.12^{\mathrm{c}}$ \\
\hline
\end{tabular}

a Factor 1 was called the hygienic orientation factor, factor 2 the line work orientation factor, and factor 3 the selfinterest orientation factor, on the basis of original variables that had high factor loadings of the factor. These factors were saved as 3 new variables. The limit of zero value of this new variable was used in defining the respondents into hygiene and non-hygiene, line work and non-line work and self-interest and non-self-interest oriented for the analyses of differences between oriented and non-oriented ones.

b Median and range (in parenthesis) on a scale: $1=$ substantially, $2=$ considerable, $3=$ moderate, $4=$ hardly any, 5 =negligible influence on hygienic working methods.

c Eigenvalue of the factor. Eigenvalue means how much the factor describes of the variation of original variables.

slaughter than those respondents who did not value that factor.

Importance of the reasons for meat inspection (Table 2) was tested by the factors. Those who emphasized self-interest of workers considered animal protection to be a more important reason for meat inspection $(\mathrm{p}<0.05)$ than those who did not emphasize a self-interest factor. They also considered the work week schedule to be less meaningful. This difference, however, was not statistically significant $(\mathrm{p}=0.06)$.

\section{Confounding variables}

Of the total number of respondents, 19 were under 45 years and were classified as young (46\%), and the 22 respondents over 45 were classified as old (54\%). Together there were 18 (44\%) male and 22 (54\%) female respondents. In one case the respondent's gender was not reported. Young or female veterinary meat inspectors emphasized the self-interest of workers more than older or male inspectors according to the t-test $(\mathrm{p}<0.05)$. If there was a significant difference between those who valued a certain factor and those who did not and such significant difference was found only among female or among male respondents, gender was considered as an interacting variable and if such significant difference was found neither among female nor male respondents, gender was considered as a confounding variable. The effect of age was analysed in the 
same way. Both age and gender were found to be confounding variables with line work factor. Because of this the differences between those who valued line work and those who did not were also tested by analysis of variance with age and gender as covariates. After this the differences concerning the line work were no more found. Age and gender of the respondents were found to be interactive variables with the hygiene and education factors. The differences between those who valued hygiene or education and those who did not were mostly found among older male respondents.

\section{Characterization of meat inspection veterinarians}

Three significant characteristic orientation factors were found. The hygiene factor of both respondents and the hygiene factor in relation to workers was defined as the first orientation term. Both of these factors were highly similar in content. The education factor was the second, and the self-interest factor of both respondents and the self-interest factor in relation to workers was the third orientation term. Because the emergency work was so typical to this orientation term it was called emergency work orientation term. Characteristic of the hygienic orientation of Finnish meat inspection veterinarians was the attitude that adoption of hygienic working methods was perceived to be dependent on situational factors, such as general hygiene, provision of proper equipment or a positive atmosphere. Education orientation emphasized education, the supervision of meat processing and work challenge. The survey revealed that the supervision of meat processing may be more challenging than meat inspection. The value placed on individual education evidently increased the application of education in practice. The respondents in the third characteristic term, emergency work orientation considered worker motivation to be dependent only on the workers themselves and were not open to influence by various situational or environmental effects.

In light of the results of this study, meat inspectors do not generally motivate workers to adopt hygienic working methods, at least not through training or education. Traditional meat inspection work, i.e. slaughter-line work and emergency slaughtering, takes up the major part of the working time of veterinary meat inspectors. Veterinary meat inspectors with either a high hygienic or educational orientation can be said to consider motivation to be formed as suggested by Tazelaar (1987). Young female veterinary meat inspectors had a higher emergency work orientation than older male inspectors. The majority of young veterinary meat inspectors are female (Rahkio et al. 1991). It is very likely that young meat inspection veterinarians perceive themselves to be more capable of performing emergency work in comparison with the other tasks of meat inspection veterinarians. Indeed, emergency work is more directly related to the practical duties of a professional veterinary surgeon. The orientation attitude of young respondents may change with time. However, more concern should be focused on both undergraduate and postgraduate training of meat inspection veterinarians in order to inculcate a hygienic or educational orientation among them. The opportunities and competences of meat inspection veterinarians to participate in the training of slaughterhouse workers should also be improved. The character of meat inspection and the work of meat inspection veterinarians is on the verge of change. Besides the traditional postmortem meat inspection, efficient process control and surveillance programmes for microbiological hazards and residues are needed (Hathaway et al. 1989, Hathaway \& McKenzie 1991). Integrated quality control during the production and processing of meat as described by Snijders et al. 
(1994) requires an even greater capacity for cooperation on the part of meat inspection veterinarians.

\section{Acknowledgements}

The authors wish to thank the Academy of Finland for providing financial support for this study.

\section{References}

Anonymous: Lihantarkastusasetus. (Meat Inspection Statue). Statute 219/60. Veterinary Department. Ministry of Agriculture and Forestry, Helsinki 1960.

Anonymous: Asetus lihantarkastusasetuksen muuttamisesta. (Meat Inspection Statue- revised). Statute 29/89. Veterinary Department. Ministry of Agriculture and Forestry, Helsinki 1989.

Anonymous: Lihahygienialaki. (Meat Hygiene Law). Statute 511/94. Veterinary and Food Department. Ministry of Agriculture and Forestry, Helsinki 1994a.

Anonymous: Lihahygieniapäätös. (Meat Hygiene Decision). Statute 11/EEO/94. Veterinary and Food Department. Ministry of Agriculture and Forestry, Helsinki 1994a.

Danzart M: Univariate procedures. In: Piggot JR (ed): Statistical Procedures in Food Research. Elsevier Applied Science Publishers, London 1986, p.19-59.

Gerats GE, Tazelaar F, Wippler R, Logtestijn JG: Motivation and other determinants of workers' hygienic practices - an empirical investigation. Proc. 28th Eur. Meet. Meat Res. Workers. Vienna 1982, 483-487.

Gerats GE: What hygiene can achieve - how to achieve hygiene. In: Smulders FJM (ed): Elimination of Pathogenic Organisms from Meat and Poultry. Elsevier Applied Science Publishers, London 1987, p. 269-283.

Gerats, GEC: Werken aan kwaliteit. (Working towards quality). $\mathrm{Ph}$. D. Thesis. The University of Utrecht. Utrecht 1990, 198 pp.

Hathaway SC, McKenzie AI, Pullen MM: Practical considerations in the application of a risk assessment model to evaluate postmortem organoleptic meat inspection systems. Proc. 10th Int. Symp. WAVFH, Stockholm 1989, 247-252.

Hathaway SC, McKenzie AI: Postmortem meat inspection programs; separating science and tradition. J. Food Prot. 1991, 54, 471-475.
Konuma H, Shinagawa K, Okayama H: Establishment of evaluation for microbial control at beef slaughterhouses in Japan. Proc. 40th Int. Cong. Meat Sci. \& Technol., The Hague 1994, S-IIB.43.

Ranta E, Rita H, Kouki J: Biometria. (Biometrics). The University Printing House, Helsinki 1991, $569 \mathrm{pp}$.

Rahkio M, Korkeala H, Uutela A, Ridell J: The female veterinary meat inspectors of Finland - how to manage in the working environment. Proc. 37th Int. Cong. Meat Sci. \& Technol., Kulmbach 1991, 135-139.

Seligmann R, Rosenbluth S: Comparison of bacterial flora on hands of personnel engaged in non-food and food industries. J. Milk Food Technol. 1975, 38, 673-677.

Snijders JMA, Berends BR, van Logtestijn JG: Revision of current meat inspection: why and how. Main papers of 40th Int. Cong. Meat Sci. \& Technol., The Hague 1994, 137-143.

Tazelaar $F$ : The human factor in the hygiene problem: problem analysis, problem solution, and implications. In: Smulders FJM (ed): Elimination of Pathogenic Organisms from Meat and Poultry. Elsevier Applied Science Publishers, London 1987, p. 251-265.

Witt JC, Kampelmacher EH: Some aspects of microbial contamination of hands of workers in food industry. Zbl. Bakt. Hyg. I. Abt. Orig. B, 1981, 172, 390-400.

\section{Sammanfattning}

Finska köttkontrollveterinärers arbetsmotivation

Frågeformulär sändes till alla finska köttbesiktningsveterinäner, som år 1990 arbetade varaktigt $\mathrm{i}$ slakteriet. Frågorna behandlade arbete och arbetsmotivation och veterinärernas uppfattning om hur slakteriarbetare godkänner hygieniska arbetsmetoder. Av 50 veterinärer i 36 slakterier, svarade $41(84 \%)$ från $30(83 \%)$ slakterier. Enligt svaren tog den traditionella köttkontrollen i slakterilinjen (15.8\%) och arbetet med nödslakteriet (15.8\%) största delen av arbetstiden. Nödslakteriet och den hygieniska kontrollen var de viktigaste uppgifterna enligt svaren. Köttets och köttprodukternas livsmedelhygieniska kvalitet var den viktigaste orsaken till köttbesiktning. Veterinärerna var av den åsikten att dom själva inte spelade någon viktig roll $\mathrm{i}$ undervisningen av arbetare, men ansåg ändå att undervisning var mycket viktigt vid införandet av hygieniska arbetsmetoder. 
På basen av svaren kunde 3 huvudslutssatser gällande köttkontrollen och slakthusarbetet dras. Den första var att den hygieniska nivån på arbetsplatsen inverkar positivt på arbetsmotivationen. Den andra var att de svarande i hög grad värdesätter utbildning och den tredje att de värdesätter nödslakteriet mera än deras andra uppgifter. Det verkar som om vete- rinärerna är något isolerade från den övriga personalen med ansvar för kvalitet och hygienen i slakteriet. Dessa fakta borde man ta större hänsyn till både i skolningen och fortutbildningen av veterinärerna. Veterinärerna borde vara så hygieniskt orienterade som möjligt, de har ju ett stort lagstadgat ansvar för hygien i slakterier samt i skär- och kallutrymmen.

(Received March 6, 1995; accepted June 28, 1995).

Reprints may be obtained from: M. Rahkio, Department of Food and Environmental Hygiene, Faculty of Veterinary Medicine, University of Hensinki, P.O. Box 57, SF-00014 Helsinki University, Finland. 